\title{
Evaluating sustainable urban transport systems: A Review study for the identification of smart mobility indicators
}

\author{
NAZAM ALI \\ Department of Civil Engineering, School of Engineering, University of Management and Technology, Lahore, \\ Punjab 54770, Pakistan
}

KEYWORDS: Sustainable Urban Transport; Performance Indicators; Smart Mobility; Urban Mobility.

ABSTRACT: Urban transport sustainability is of prime importance for achieving desired urban outcomes which impact economic, social and accessibility dimensions. In many of the growing cities, everyday mobility is influenced by several factors which hinder sustainable and smart transport operations. This study is aimed at identifying the indicators to measure the sustainability of the transport systems, with special focus on urban mobility. A systematic literature review was conducted for this purpose, between 2000 and 2019, from databases including Scopus, Web of Science, KCI-Korean Journal Database, Russian Science Citation Index, and SciELO Citation Index. An assessment of the economic, social, and accessibility indicators of sustainability on urban transport systems was carried out. This research work has allowed the identification of the main indicators of sustainability referred by different researchers in the field of urban transport systems. Based on the careful bibliographic analysis, a set of the identified indicators is proposed so that reviewed indicators can be utilized more objectively and accurately for smart urban mobility patterns. This review study can be helpful in assisting researchers who are exploring to evaluate sustainability perspectives in urban transport systems.

\section{INTRODUCTION}

In many of the rapidly growing cities, the increased demand of urban mobility has resulted in the deterioration of the user-friendliness and suitability of using the existing transport systems because of traffic congestions, travel costs and accessibility. Therefore, the identification and documentation of the main principles of sustainability in the field of urban mobility are of very prime concern (World Bank, 1996). In the recent decades, the researchers have started to consider and investigate the legitimate factors that are apparently the main cause of worsening the sustainable urban mobility. For effective policy measures, it is important to study and highlight some of the factors, which might possibly directly or indirectly affect the performance of the urban transport system and its sustainability. Therefore, it has become much important than ever before. This will not only help in determining the performance of the transport systems but will also help in quantifying the impacts of the indicators over a period of time. In the developing megacities, which have a greater growth potential but limited resources, it is an urgent issue to determine the set of indicators for the quantification of sustainable mobility in advance.

Therefore, the identification of the measurable indicators is inevitable to determine the level of sustainable mobility. Indicators in the field of transport systems play a vital role for smart mobility operations due their specific characteristics (Marsden \& Snell, 2009). In the usual terminology, indicators are set of; targeted, compressed, selected, qualitative and quantitative variables, which provide relevant information about a phenomena and project public's opinion for the decision makers (Guy \& Kibert, 1998). They can also be defined as "things that we quantify using different statistical tools based on raw data, databases or through relevant stake-holders, in the form of surveys / on-filed measurements, or using different spatio-temporal data analysis tools etc, for the evaluation of the progress made to achieve certain goals and objectives"
(Litman, 2007). The United Nations through its Agenda 21 (UN, 1992) fortified different national and global establishments to develop their indicator systems, which they can widely use and adopt as policy measures for attaining intended goals. These indicator approaches share almost same pattern for the establishment of their arguments; starting from the selection of the parameters (i.e., selection of indicators) and concluding on end goals (i.e., quantification or assessment of the developments made for sustainable transport systems and smart mobility operations). So, this paper aims to propose a framework of indicators for the evaluation of the sustainable transport systems. This proposed framework can be employed more objectively and accurately to growing megacities, for the quantification of sustainable mobility, which need immediate attention due to their low sustainable mobility. Thus, this framework can be an operative tool for the policy makers and stakeholders in planning effective transport policies towards minimizing negative menaces on urban mobility.

The general concept of sustainable urban mobility is quite a subjective research dimension; it may include range of parameters which are deemed necessary by different researchers for given circumstances. However, the common concern of most of the research studies for a set of defined parameters usually revolve around their quantification methods / approaches. The main difference lies in the objectivity of the proposed policy measure on urban mobility and its implications on the subjected region from sustainability standpoint. It is much widely accepted fact that transport is an important sector which is main source of economic growth and employment. According to an estimation, there are around $10 \mathrm{mil}-$ lion people which are directly associated with the transport industry in the European Union (EU), which constitute about $5 \%$ of the total employment in the EU. It is worth mentioning that the transport relevant activities amount for $5 \%$ of the total GDP of the EU. According to the report by (OECD, 1999), transport externalities cost on average around $5 \%$ of 
the GDP in the developing nations. Applying sustainable transport planning approaches, enable the optimized operations of the existing transport infrastructure, development of effective traffic management strategies and provision of cost effective mobility options through the use of advanced information systems, rather than consuming huge capital for the expansion and construction of roads, and additional transport infrastructure projects (Litman, 2007).

Smart mobility and economic sustainability of the transport system have become an important part of the human need, which is a source of social interactions of people and movement of goods. This strong relationship between economic return and sustainable urban transport system, in particular among transport infrastructure, its feasibility for sustenance and operations is much necessary (Jeekel, 2017; Noy \& Givoni, 2018). A sustainable urban transport network must provide a dynamic network connecting people and different parts of the city in such a way that it must improve the socio-economic development, wellbeing and living standards throughout the generations between- or within different parts of the city-connections (Badassa et al., 2020). However, the extent up to which the social dimension of the sustainable urban transport is concerned, it is not explicitly explored in the literature. It is equally important to highlight how different barriers in the transport systems contribute to the socio-spatial inequities and social injustices, especially when it lies along lines of different races and social classes. For example, the inequitable excess to employment among different races results in low-wage, less skilled labour, which results in many of the problems pertinent to urban transport systems, making them less accessible between residential choices and workplaces, making more costly commutes, higher levels of unemployment, and compromised wages (Boschmann \& Kwan, 2008; Jeekel, 2017). The accessibility dimension of sustainable urban transport systems debate about how the transport planning process must ensure the people's ability to reach different activity locations. The planning process must ensure the sustainability through the integration of multimodal integration (mobility options, promotion of active transit modes such as walking, bicycling, public transport, and shared mobility) which ensures the social equity in the transport system. In other words, the accessibility dimension of sustainable transport system emphasizes on the concept of reachability in line with transport equality in the sustainable urban transport system (Ali et al., 2021; Brussel et al., 2019; Oviedo \& Guzman, 2020).

\subsection{Selection and Variability of the Indicators}

In the development of the proposed framework of indicators, the selection process for the indicators is of prime importance. It is imperative that the identified indicators must comprehensively measure the progress towards identified goals of sustainability of the transport systems (Litman, 2007; Marsden \& Snell, 2009). The selected indicators must be in compliance with the internationally recognized criteria of comprehensiveness, clarity, policy relevance and informative accessibility for smart and sustainable mobility operations (Liu et al., 2020). They must be primarily consistent in addressing the issues raised in the selected domain of sustainability in the transport sector (Litman, 2013). They should be pertinent to the defined policies and objectives and must provide clear and explicit information in terms of economic, environmental, and societal sustainability and must be able to quantify the performance of the transport system over time (Mitchell, 1996; Zheng et al., 2013). The indicated indicators must explain the complex operations into simpler and easy way which should be understandable for the experts as well as general public; thus, visualizing the clarity and transparency of the employed scientific approaches, validating the soundness of the assumptions made. The structure of the identified indicators must be consistent and should assist the setting of the objectives and goals, which are indicated as threshold reference values (Litman, 2013; Sdoukopoulos et al., 2018). For the purpose of requiring the data, it must be collected through approved scientific methods and should be relevant, consistent, cost and time effective (Litman, 2009; Mitchell, 1996).

The general framework for the assessment of the transport indicators in the developing countries utilized by the World Bank with some modalities is shown in Figure 1. It adopted the $3 \mathrm{M}$ terminology to illustrate the linkage between the criterion parameter in the selection of indicators. As it is considered mandatory that the role of the indicators is very much important to assess the sustainability of any project (Dobranskyte-Niskota et al., 2007). That is why limiting the indicators for the management perspectives is also an important consideration along with measurement and monitoring concerns. The linkage of criteria scheme for the selection and assessment of indicators is shown in Figure 1.

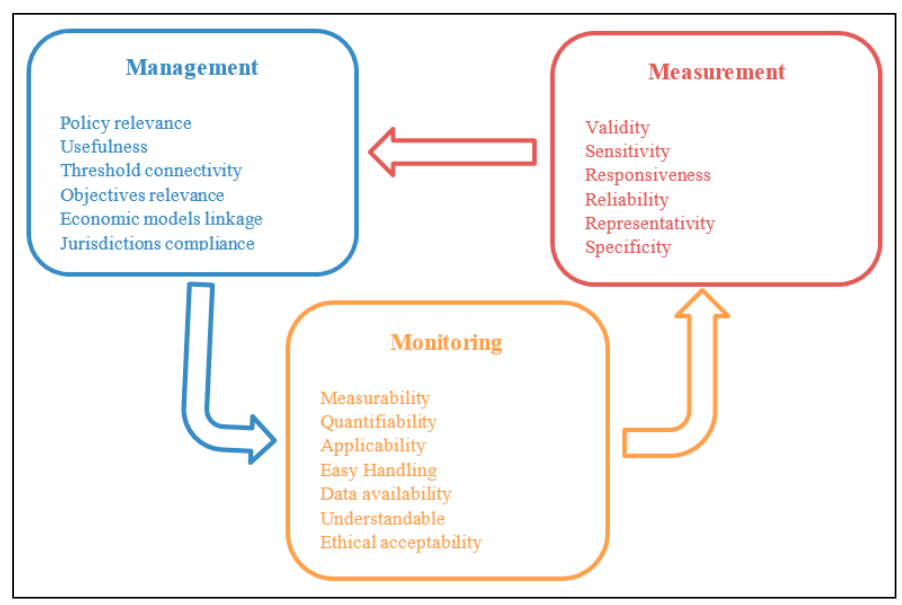

Figure 1: Linkage scheme between selection criteria of indicators (source: own study on the basis of (Dobranskyte-Niskota et al., 2007)

However, it is pertinent to mention that most of the times, terms "Sustainable Mobility" and "Smart Mobility" are considered acronym of each other. In the paradigm of "Sustainable Mobility", traveling is considered as a valued activity which is derived based on demand. It includes the managing and controlling the demand based on best possible practices with the use of minimum resources. It includes the minimization of travel costs and times when moving between two destinations from the perspectives of 'reasonable travel time'. It considers the reliability of the transport services as well and put much weight on travel experiences and quality of the travel time, not just quantity measurement. In short, "Sustainable Mobility" relies on the foundation of the transport system where the need to travel is reduced in conjunction with the promotion of more sustainable modal shift - specially from private personalized modes of travel to active transport modes such as walking, bicycling and public transport (Jeekel, 2017; Oviedo \& Guzman, 2020). However, the concept of "Smart Mobility" paradigm encourages the need of mobility by facilitating how easy it is to travel. The methodical origin of "Smart Mobility" is derived from the terminology of "Smart City". The term "Smart City" is used by many of the global organizations, local and national governments to use it as a tool of economic growth and show global "presence" when adopted (Noy \& Givoni, 2018). In the domains of "Smart Mobility", all the initiatives that are undertaken by different governments and organizations, fall in two broader perspectives. First, the use and encourage- 
ment of alternative fuels and propulsion (hybrid, electric, fuel cells, and CNG etc,) vehicles. In the second domain, different Information and Communication Technologies (ICTs) are integrated and assimilated in the transport infrastructure to update the travel forms for making more informed decisions as compared to traditional transport systems. Some of the examples of "Smart Mobility" include but not limited to; automated and autonomous vehicles, connected and integrated vehicles (Vehicle to Vehicle (V2V) and Vehicle to Infrastructure (V2I) systems), app-based transport systems, Intelligent Transport System (ITS) (Litman, 2007; Marsden \& Snell, 2009; Ramani et al., 2011), and Mobility as a Service (MaaS), which shares some of the common characteristics, as a whole or part of, "Smart Mobility". Further details of "Smart Mobility" will leads beyond the scope of this research study (Noy \& Givoni, 2018).

Though, the definitions of the sustainability are much variant and depends upon the scope of its wide dimensions. However, in the field of transport and mobility, it highlights the developments in the transportation infrastructure which are in the best possible compliance to meet the needs of the commuters / passengers without compromising the ability of the future generations and balancing the acceptable ratios between operators' cost-benefit concerns in a justifiable manner.

The above section discussed the basic concepts of the sustainable urban mobility and the remaining research study is divided into four different parts. In part 2, the methods employed for the systematic literature review and framework for the selection of the indicators are mentioned. Part 3 includes the co-citation network and a set of identified indicators (findings of the study). Finally, the conclusions of this research study are summarized. Also, future research directions are proposed for other researchers to explore new dimensions in the field of sustainable urban mobility.

\section{RELATED RESEARCH WORK}

\subsection{Methodology}

As the main objective of this research study include the identification of the indicators for sustainable transport systems with special focus on urban mobility. Therefore, a systematic literature review was conducted by adopting the approach proposed by (Thomé et al., 2016) for identifying core factors and / or indicators associated and used by different researchers in this particular research direction of sustainable transport and urban mobility. For this purpose, the databases from ScienceDirect, Scopus, Web of Science, KCI-Korean Journal Database, Russian Science Citation Index, and SciELO Citation Index were selected to search the research articles from 2000 to 2019. The searches were carried out with main group of keywords: (1) sustainable urban transport, (2) smart urban mobility, (3) mobility performance indicators / indices / factors, and (4) transport performance indicators / indices / factors. The first two groups restrict our searches in the field of urban mobility environments, while the last two groups highlighted the criterion parameters for sustainable and smart mobility both in terms of passenger and freight transportation. As a result of these searches, it was found out that there are 6 articles which are best match of our desired searches, rest of the 38 articles are included by snowball technique. So, a total of 44 research articles are included in our research study. The co-citation network was formed using VOSviewer 1.6.16 software, which is a software for the construction and visualization of bibliometric networks. The co-citation networks are constructed based on the citation, coupling, co-citation, and co-authorship relationships. In this study, a co-citation network is constructed for the sake of highlighting relevant literature studies.

\subsection{Framework for the Selection of Indicators}

In this research study, the systematic literature review was conducted to formulate the criteria for the selection of the smart mobility and sustainable transport indicators. In the planning stage of this research study, keywords and basic set of inclusion and exclusion of the indicators was defined. This research work was framed to identify the links between smart urban mobility and sustainable urban transport in order to identify the indicators in economic, social, and accessibility dimensions. The keywords identified for the research study include, "smart urban mobility", "sustainable urban transport", "mobility performance indicators / indices / factors", "transport performance indicators / indices / factors". The inclusion criteria were determined based on, if the indicators are reported by research articles which are peer reviewed, full-text available and online. The studies other than the mentioned inclusion criteria were excluded for consideration of the indicators. The research studies were collected from different databases such as ScienceDirect, Scopus, Web of Science, KCI-Korean Journal Database, Russian Science Citation Index, and SciELO Citation Index. The literature was collected from 2000 - 2019. The searches were conducted based on the inclusion of titles / abstracts and topics from the data sources. All of the collected articles were "eye-balled" to check the consistency and correctness of the keywords (Yin, 1994). Afterwards, careful screening of the research studies was done to check their relevancy against defined research dimensions of indicators pertinent to economic, social, and accessibility issues. The categorization of the indicators in the relevant research dimension was done based on its most relevance with the research topic. The main themes of the indicated indicators were cross-checked with reviewed literature studies (Buzási \& Csete, 2015; Danielis et al., 2018; Dobranskyte-Niskota et al., 2007; Gillis et al., 2016; Haghshenas \& Vaziri, 2012; Kim \& Author, 2011; Litman, 2007; Sdoukopoulos et al., 2019; Shiau \& Liu, 2013; Zheng et al., 2013; Zietsman et al., 2003) for verification and relevance of the specific research dimension / theme. The procedure followed for the selection and identification of indicators is shown in Figure 2.

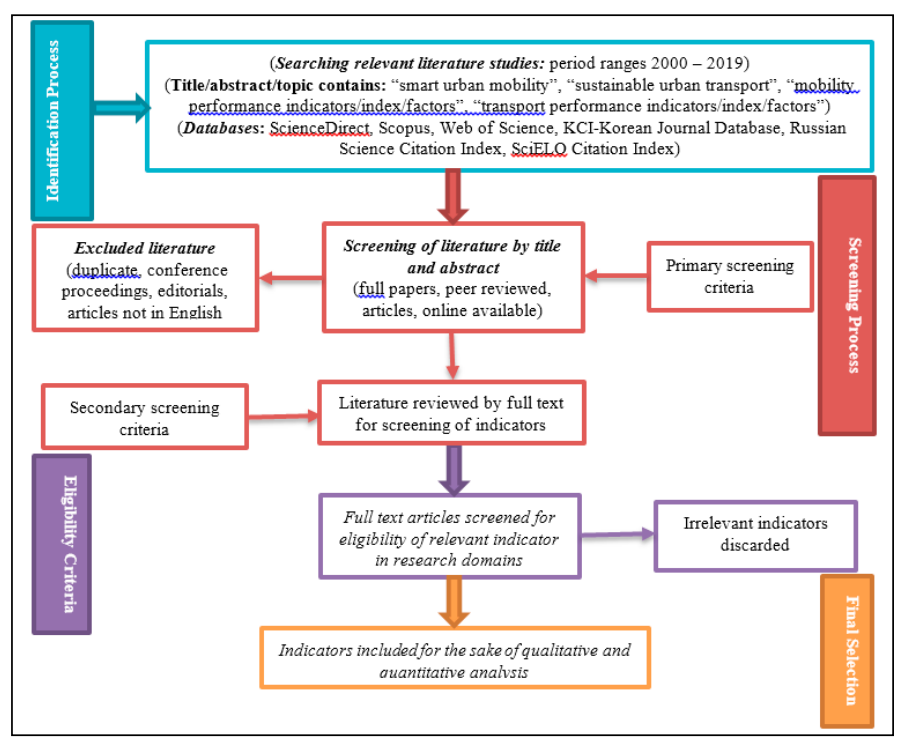

Figure 2: Proposed framework for the identification of the indicators

\subsection{Analysis of the Reviewed Literature}

The analysis of the 26 selected studies revealed the concentration of the factors / indicators which are deemed important in the field of sustainable and smart urban mobility. Many of the referred articles incorporate the factors which are relevant to environment, economic and social factors (Campos 
et al., 2009; M. da S. Costa, 2008; Kim \& Author, 2011; Litman, 2013; Marletto \& Mameli, 2012). However, some of the studies showed that these factors overlap with each other, which greatly impact the urban mobility (Dobranskyte-Niskota et al., 2007; Haghshenas \& Vaziri, 2012; Litman, 2009). This research study, focused on both passenger and freight transport sustainability factors, considering smart urban mobility as a main impacted dimension as a result of these criterion parameters. (Campos et al., 2009) devised the index calculated approach to evaluate economic, environmental and social dimensions of sustainability in the urban settings. (Haghshenas \& Vaziri, 2012) ranked different world cities from economic, environmental, and social point of view using composite index criterion and they suggested 3 indicators in each group. However, (Litman, 2009) investigated the quality and availability of data required for the selection of sustainable indicators. Some of the pertinent research studies in the defined time span (2000 2019) and relevant indicators studied by different researchers are listed in Table 1, which shows the urgency and need of research in sustainability.

\section{FINDINGS OF THE STUDY}

Despite the strict criteria for the selection of the indicators of sustainability in the urban transport and mobility operations (Steadman et al., 2004), they may vary subject to combined outcome of the following reasons; the vague conceptuality of the sustainability, the augmented interest in the field of sustainability, the complexities pertinent to the urban transport systems, demographic features of the subjected area, and quality of the available data (Sdoukopoulos et al., 2019). Regardless of the vague nature of the sustainability concept, there is an ever-increasing trend in this research direction as shown in Figure 3. The results of the relevant research outs (Web of Science, 2020) are demonstrated for the time span of 2000 - 2019. So, it can be argued that the research interests of the researchers in sustainable urban transport and transport performance indicators remained high in absolute terms. The cumulative research outputs were selected as they can facilitate in drawing the conclusions based on the pertinent literature studies.

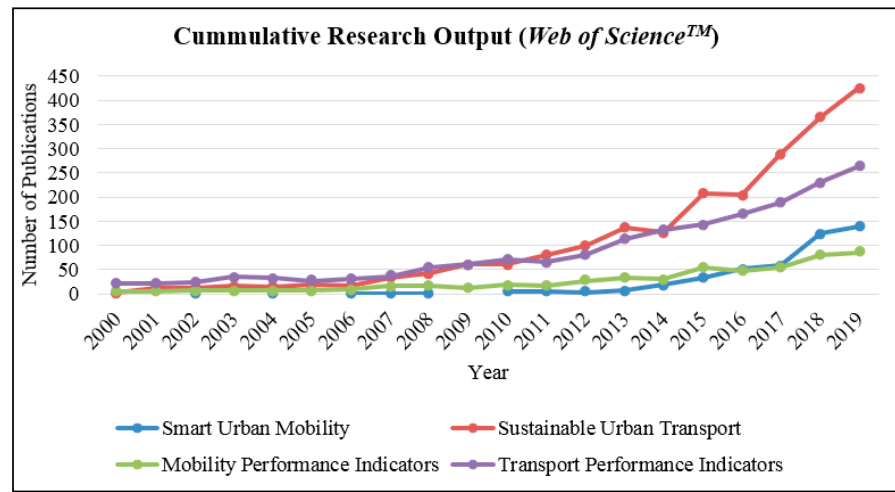

Figure 3: Research output searches from Web of Science pertinent to the referred topics between time span of $2000-2019$
However, the variability of the indicators for sustainable urban transport and smart mobility is also greatly influenced by different spatial levels (Sdoukopoulos et al., 2019), certain policy objectives (Olofsson et al., 2016), data quality and availability (Kristle Nathan \& Reddy, 2013).

Furthermore, a bibliometric analysis was done to investigate the influence of economic, social and accessibility factors on sustainable urban transport and mobility systems. It was revealed that (Joumard et al., 2010; Marsden \& Snell, 2009; Nicolas et al., 2003; Ramani et al., 2011; Zietsman et al., 2003) were the most cited research studies in the defined time frame. The co-citation network of the referred research studies is illustrated in Figure 4.

\subsection{Quantification of the Indicators}

For the clarity of the evaluation processes, the quantification of the indicators and a framework to consolidate and demonstrate is shown in Table 2. In the proposed framework, it was sought to include three directions pertinent to smart and sustainable urban transport systems of economic, social, and accessibility importance. These dimensions are derived by the most cited publications, as shown in Figure 4. The sole objective of the proposed study was that these proposed indicators can be used more objectively and accurately for smart urban mobility patterns. There were 33 indicators proposed as can be seen in Table 2 .

The research articles analysed in this study were categorized based on qualitative and quantitative approach of analysis. This literature review study was not only restricted to the identification of the relevant parameters about sustainable transport and smart mobility but also proposed a comprehensive framework which can be considered as a selection criterion for the included parameters (referred in Table 2). Usually, the qualitative approaches of analysis need less efforts and are less accurate as compared to quantitative approaches (Christiansen \& Hald, 2012). In this research study, the quantitative approaches for quantification of economic, social and accessibility dimensions of sustainable urban mobility are proposed. The quantified indicators were analysed centred on the infrastructure quality, serviceability, and operations smoothness from the perspectives of the revealed dimensions.

In many of the referred studies, the analysis of the parameters was carried out for a specific dimension and the effective operations management and optimization strategies are reported. The indicators reported in this research study based on results revealed that sustainable urban transport, transport evaluation, smart city, smart mobility, mobility patterns were the most reported research directions.

This approach could help in the identification of the critical factors for sustainable urban transport and smart mobility for global perspectives without limiting their scope for the specific regions in the given dimensions of sustainability. In this way, the categorization proposed by this research study could assist planners / managers and stakeholders on the discussed topic for better sustainable transport systems.

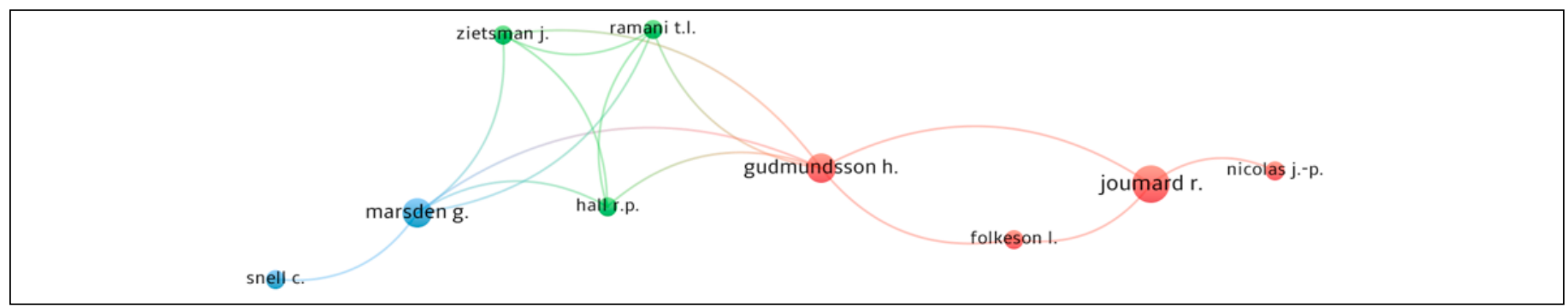

Figure 4: The Co-citation network 


\begin{tabular}{|c|c|c|c|c|}
\hline Paper & Research Aim/s & Studied Indicators & $\begin{array}{l}\text { Spatial } \\
\text { level }\end{array}$ & $\begin{array}{l}\text { Country } \\
\text { of Study }\end{array}$ \\
\hline $\begin{array}{l}\text { (Zietsman et al., } \\
\text { 2003) }\end{array}$ & $\begin{array}{l}\text { The index for sustainable transport system was developed based } \\
\text { on South Africa and United States of America as a case study. } \\
\text { The performance measure was quantified on aggregate and dis } \\
\text { aggregate level. }\end{array}$ & $\begin{array}{l}\text { Economic, social, and } \\
\text { environmental }\end{array}$ & Regional & USA \\
\hline $\begin{array}{l}\text { (M. S. Costa et al., } \\
\text { 2005) }\end{array}$ & $\begin{array}{l}\text { The identification of the sustainability indicators extracted from } \\
\text { national and international experiences for Brazil and Portugal. }\end{array}$ & $\begin{array}{l}\text { Environment, mobility } \\
\text { management, } \\
\text { infrastructure, spatial, and } \\
\text { socio-economic }\end{array}$ & Urban & Brazil \\
\hline $\begin{array}{l}\text { (Dobranskyte-Niskota } \\
\text { et al., 2007) }\end{array}$ & $\begin{array}{l}\text { Review of the existing sustainability indicators for priority- } \\
\text { setting, policy formulation and evaluation perspectives. }\end{array}$ & $\begin{array}{l}\text { Environment, infrastructure, } \\
\text { safety, and economic }\end{array}$ & Regional & Italy \\
\hline (Litman, 2007) & $\begin{array}{l}\text { The selection of the indicators for transport planning } \\
\text { perspectives. }\end{array}$ & $\begin{array}{l}\text { Economic, social, and } \\
\text { environmental }\end{array}$ & Global & Canada \\
\hline (M. da S. Costa, 2008) & $\begin{array}{l}\text { 1. Identification of the concepts that shape sustainable urban } \\
\text { mobility. } \\
\text { 2. Development of tool for assessing urban mobility conditions. } \\
\text { 3. Evaluation of the proposed framework through its application } \\
\text { in a medium sized city. }\end{array}$ & $\begin{array}{l}\text { Environment, mobility } \\
\text { management, } \\
\text { infrastructure, spatial, and } \\
\text { socio-economic }\end{array}$ & Urban & Brazil \\
\hline (Litman 2008) & $\begin{array}{l}\text { Description of the factors for considering sustainability } \\
\text { indicators and discussing issues pertinent to data quality. }\end{array}$ & $\begin{array}{l}\text { Economic, social, and } \\
\text { environmental }\end{array}$ & Global & Canada \\
\hline $\begin{array}{l}\text { (Marsden \& Snell, } \\
\text { 2009) }\end{array}$ & $\begin{array}{l}\text { The implications for the application of sustainability indicators } \\
\text { in UK. }\end{array}$ & Social and environmental & Regional & UK \\
\hline (Campos et al., 2009) & $\begin{array}{l}\text { The evaluation process for the set of sustainability indicators in } \\
\text { Brazil }\end{array}$ & $\begin{array}{l}\text { Environment, social and } \\
\text { economic }\end{array}$ & Urban & Brazil \\
\hline (Litman, 2009) & $\begin{array}{l}\text { The investigation about the quality and availability of data for } \\
\text { sustainability indicators. }\end{array}$ & $\begin{array}{l}\text { Economic, social, and } \\
\text { environmental }\end{array}$ & Global & Canada \\
\hline (Joumard et al., 2010) & $\begin{array}{l}\text { The development of the processes to integrate complex } \\
\text { environmental indicators in decision processes in European Union. }\end{array}$ & Environmental & National & $\mathrm{EU}$ \\
\hline (Kim and Han 2011) & $\begin{array}{l}\text { The measurement and evaluation of sustainability in OECD } \\
\text { countries with relevance to the Korean transportation } \\
\text { sustainability indicators. }\end{array}$ & $\begin{array}{l}\text { Environmental, social, and } \\
\text { economic }\end{array}$ & Regional & $\begin{array}{l}\text { South } \\
\text { Korea }\end{array}$ \\
\hline $\begin{array}{l}\text { (Haghshenas } \\
\text { \& Vaziri, 2012) }\end{array}$ & $\begin{array}{l}\text { The creation of the sustainability indicators based on MCDST } \\
\text { database by combination of standardized indicators. }\end{array}$ & $\begin{array}{l}\text { Environmental, social, and } \\
\text { economic }\end{array}$ & Global & Iran \\
\hline $\begin{array}{l}\text { (Christiansen } \\
\& \text { Hald, 2012) }\end{array}$ & $\begin{array}{l}\text { The assessment of environmental emissions of different } \\
\text { Norwegian cities with the set of indicators defined by The } \\
\text { Institute of Transport Economics (Norway). }\end{array}$ & Environmental & Urban & Norway \\
\hline $\begin{array}{l}\text { (Marletto \& Mameli, } \\
\text { 2012) }\end{array}$ & $\begin{array}{l}\text { The development of the procedure to evaluate performance of } \\
\text { policy indicators through involvement of citizens. }\end{array}$ & $\begin{array}{l}\text { Social, environmental, and } \\
\text { economic }\end{array}$ & National & Italy \\
\hline $\begin{array}{l}\text { (Kristle Nathan } \\
\text { \& Reddy, 2013) }\end{array}$ & $\begin{array}{l}\text { Proposal of Multi-view Black-box (MVBB) framework for the } \\
\text { development of sustainable indicators (SDIs) in urban settings. }\end{array}$ & $\begin{array}{l}\text { Social, economic, and } \\
\text { ecological }\end{array}$ & National & India \\
\hline (Gössling, 2013) & $\begin{array}{l}\text { For the city of Copenhagen, the discussion on the success and } \\
\text { reproducibility of cyclist policies in urban transition framework. }\end{array}$ & Safety & Urban & Sweden \\
\hline (Zheng et al., 2013) & $\begin{array}{l}\text { The development of the complex metrics indices system for the } \\
\text { identification of sustainability indicators. }\end{array}$ & $\begin{array}{l}\text { Environmental, economic, } \\
\text { and social }\end{array}$ & National & USA \\
\hline (Litman, 2013) & $\begin{array}{l}\text { The development of a new paradigm for sustainable transport } \\
\text { planning processes. }\end{array}$ & Infrastructure and safety & National & Canada \\
\hline (Reisi et al., 2014) & Quantification of sustainability in urban transport systems. & $\begin{array}{l}\text { Environmental, social, and } \\
\text { economic }\end{array}$ & Urban & Australia \\
\hline $\begin{array}{l}\text { (Mitropoulos } \\
\text { \& Prevedouros, 2016) }\end{array}$ & $\begin{array}{l}\text { Sustainability assessment in transport planning through } \\
\text { a vehicle-based approach. }\end{array}$ & $\begin{array}{l}\text { Environmental, technology, } \\
\text { energy, economic and social }\end{array}$ & Urban & USA \\
\hline $\begin{array}{l}\text { (Munira \& Santoso, } \\
\text { 2017) }\end{array}$ & $\begin{array}{l}\text { The evaluation of the environmental, social, and economic } \\
\text { indicators of urban transport systems from sustainability point } \\
\text { of view through the lens of public perceptions. }\end{array}$ & $\begin{array}{l}\text { Environmental, social, and } \\
\text { economic }\end{array}$ & Urban & Bangladesh \\
\hline (Danielis et al., 2018) & $\begin{array}{l}\text { The estimation of the composite indicators of sustainability in } \\
\text { the Italian cities using nested structure. }\end{array}$ & $\begin{array}{l}\text { Accessibility and } \\
\text { liveability. }\end{array}$ & Urban & Italy \\
\hline $\begin{array}{l}\text { (Sdoukopoulos et al., } \\
\text { 2018) }\end{array}$ & $\begin{array}{l}\text { The use of social media platform to assess the sustainable urban } \\
\text { mobility indicators. }\end{array}$ & $\begin{array}{l}\text { Communal and } \\
\text { accessibility. }\end{array}$ & Urban & Greece \\
\hline $\begin{array}{l}\text { (Sdoukopoulos et al., } \\
\text { 2019) }\end{array}$ & $\begin{array}{l}\text { The analysis and metrics generation from the available urban } \\
\text { sustainability indicators for better policy perspectives. }\end{array}$ & $\begin{array}{l}\text { Social, environmental, } \\
\text { economic and accessibility }\end{array}$ & Urban & Greece \\
\hline $\begin{array}{l}\text { (Yigitcanlar et al., } \\
\text { 2019) }\end{array}$ & $\begin{array}{l}\text { Assessment of the smart city terminology through its } \\
\text { relationship with urban sustainability. }\end{array}$ & Accessibility and social & Urban & Australia \\
\hline
\end{tabular}

Table 1: Reviewed literature studies pertinent to sustainable transport and smart mobility indicators between 2000 - 2019 


\begin{tabular}{|c|c|c|}
\hline $\begin{array}{l}\text { Sustainability } \\
\text { Dimension }\end{array}$ & $\begin{array}{l}\text { Sustainability } \\
\text { Indicator }\end{array}$ & Quantification of the Indicator \\
\hline \multirow[t]{10}{*}{ Economic } & Traffic congestion & Translation of the congestion time into congestion cost \\
\hline & Accident damages & The estimation of the damage caused to the transport infrastructure as a result of an accident \\
\hline & Infrastructure costs & The percentage amount of money invested for infrastructure construction w.r.t. GDP of the country \\
\hline & Operation costs & $\begin{array}{l}\text { Improve efficient pricing system (road maintenance, parking, fuel etc., costs) by encouraging } \\
\text { active-transit modes and reduce portion of GDP devoted to transport }\end{array}$ \\
\hline & Energy consumption & The fuel costs for the operation of the transport infrastructure w.r.t. per capta GDP \\
\hline & Land-use objectives & Transport system design to maximize the efficiency of land-use \\
\hline & Transport efficiency & Average monthly revenue generation surplus of the direct and indirect operating costs \\
\hline & $\begin{array}{l}\text { Public transport } \\
\text { subsidies }\end{array}$ & Public expenditures, investments and subsidies provided to encourage use of public transport \\
\hline & Economic productivity & The number of new jobs created in the transport sector \\
\hline & Transport external costs & The indirect costs amounting operation costs for the sustenance of the transport strategy \\
\hline \multirow[t]{16}{*}{ Social } & Impacts to habitats & The number of individuals / habitats displaced as a result of new construction \\
\hline & Institutional aspects & The structures/behaviours of social order and cooperation between different stakeholders \\
\hline & Health aspects & The mental/physical/emotional aspects of the transport strategy on the community \\
\hline & Social equity & The inclusion of different ethnic/racial and female groups in using the facility \\
\hline & Active citizens & The average number of the citizens regularly using the transport facility \\
\hline & Affordability & The economic viability to ride transport facility by maximum economic groups of the society \\
\hline & Commuting spatiality & The number of CBDs / zones covered spatially \\
\hline & Pollutant's exposure & Protect and reduce the exposure of humans to harmful pollutants by promoting active transit means \\
\hline & Trips from/to schools & The frequency of the trips to/from the main schools in the community \\
\hline & Inclusive communities & $\begin{array}{l}\text { Promoting inclusive behaviour in the communities by improving street designs and encouraging } \\
\text { walkability and cyclability. }\end{array}$ \\
\hline & Safety and health & Minimization of crashes and improving physical fitness through walking and bicycling. \\
\hline & Traffic fatalities & Number of traffic fatalities per 1000 persons \\
\hline & Gender-based equity & $\begin{array}{l}\text { A well-documented jurisdiction system to eliminate all types of gender-based decimations in the } \\
\text { transit system }\end{array}$ \\
\hline & Assault protection & $\begin{array}{l}\text { Clear guidelines and implementation strategies for the safety of the personal space of the } \\
\text { passenger especially female travellers. }\end{array}$ \\
\hline & Special discounts & $\begin{array}{l}\text { Special discount offers for elderly, children, pregnant females, and unprivileged members of the } \\
\text { community }\end{array}$ \\
\hline & Aesthetics & The quantitative measurement of the defined qualities of aesthetics \\
\hline \multirow[t]{7}{*}{ Accessibility } & $\begin{array}{l}\text { Impacts of } \\
\text { disadvantaged mobility }\end{array}$ & The gap/discriminatory divides measurement between socially/physically impaired groups \\
\hline & Reliability & The satisfaction of the riders about scheduling quality of the transport facility \\
\hline & Modal integration & $\begin{array}{l}\text { Integration with other transport modes for maximum utility of the facility for the encouragement } \\
\text { of female commuters specially in socially and religiously restricted regions }\end{array}$ \\
\hline & Mobility options & The number of available transport modes between different CBDs / zones \\
\hline & Women's transit safety & $\begin{array}{l}\text { Transit safety of female travellers should be framed in a wider context and should be addressed in } \\
\text { terms of joint responsibility with inter-sectoral actions. }\end{array}$ \\
\hline & Route connectivity & The number of routes connected to spatially cover different CBDs / zones \\
\hline & Demand responsiveness & $\begin{array}{l}\text { The ability of the transport system to accommodate demand of commuting which can be measured } \\
\text { through surveys, manual highway capacity methods or control system equipment }\end{array}$ \\
\hline
\end{tabular}

Table 2: Quantification of the sustainable mobility indicators

\section{CONCLUSION AND FUTURE RESEARCH DIRECTIONS}

This research study was conducted to extract the most relevant indicators for urban sustainability and smart mobility from the existing literature review. A bibliometric analysis was conducted, and co-citation network is shown which highlighted pertinent and frequently referred studies by different researchers. Based on the frequently mentioned parameters, a comprehensive set of indicators for sustainable urban mobility, the illustration of their taxonomy and a framework was proposed to illustrate them (Table 2). The bibliometric analysis revealed the influence of economic, social and accessibility relevance indicators on smart urban mobility (Table 1). This research study allowed the identification of the vital parameters and the most recognized research studies in the field of sustainable urban transport and smart mobility.

The reported analysis of the literature review revealed that there is still a gap existent between the trade-offs of "Sustainable Mobility" and "Smart Mobility", which is also explained in this review article. To fill the gap, a comprehensive framework of indicators is proposed, which is based on the principles of 
transport sustainability and smart mobility by (Campos et al., 2009; Haghshenas \& Vaziri, 2012; Kim \& Author, 2011; Litman, 2007, 2009; Sdoukopoulos et al., 2019; Shiau \& Liu, 2013; Zietsman et al., 2003). The main idea behind the proposal of the set of the identified indicators was that the reviewed indicators can be utilized more objectively and accurately for smart urban mobility patterns. This identification will enable the characterization and quantification of the set of indicators which can be used to measure the level of transport sustainability and smart mobility in the emerging megacities. This analysis approach can allow the comparison of sustainable transport systems and smart mobility between regions of the same city, different cities, and different regions of a country to identify the critical elements in the infrastructure quality, serviceability, and operations smoothness, which lack from sustainable and smart urban mobility perspectives. The development of the sustainable mobility and transport indicators have made highly attractive notion for stakeholders and policy makers. Thus, it will help policy makers in identifying the potential indicators and assist them in effective planning and policy formation for the reduction of the negative impacts in the urban mobility, refining sustainable and smart transportation operations. These findings seek to explore the prospective research dimensions in the said field for critical evaluation and debate on the selection of smart mobility and sustainable transport indicator. However, it is pertinent to mention that in the future research, gender-based sustainable mobility indicators would be deeply focused, discussed and proposed because public transit systems are commonly a fertile territory for sexual harassment and other types of abuses specially in overcrowding situations. Additionally, this study was restricted to identify the indicators relevant to the economic, social and accessibility domains of sustainability. The indicators relevant to the environment have not been included in this study, though they have been extensively studied by different researchers. For the continuation of this study, environmental domain of sustainability would also be included and researched.

\section{REFERENCES}

Ali, N., Abdullah, M., \& Javid, M. A. (2021). Accessibility-based approach: Shaping travel needs in pandemic situation for planners' perspectives. Engineering Journal, 25(1), 15-22. https://doi.org/10.4186/ej.2021.25.1.15

Badassa, B. B., Sun, B., \& Qiao, L. (2020). Sustainable transport infrastructure and economic returns: A bibliometric and visualization analysis. Sustainability (Switzerland), 12(5), 1-24. https://doi.org/10.3390/su12052033

Boschmann, E. E., \& Kwan, M. P. (2008). Toward socially sustainable urban transportation: Progress and potentials. International Journal of Sustainable Transportation, 2(3), 138-157. https://doi.org/10.1080/15568310701517265

Brussel, M., Zuidgeest, M., Pfeffer, K., \& Van Maarseveen, M. (2019). Access or accessibility? A critique of the urban transport SDG indicator. ISPRS International Journal of Geo-Information, 8(2), 1-23. https://doi.org/10.3390/ijgi8020067

Buzási, A., \& Csete, M. (2015). Sustainability indicators in assessing urban transport systems. Periodica Polytechnica Transportation Engineering, 43(3), 138-145. https://doi. org/10.3311/PPtr.7825

Campos, V. B. G., Ramos, R. A. R., \& De Miranda E Silva Correia, D. (2009). Multi-criteria analysis procedure for sustainable mobility evaluation in urban areas. Journal of Advanced Transportation, 43(4), 371-390. https://doi.org/10.1002/ atr.5670430403

Christiansen, P., \& Hald, M. (2012). Indicators for sustainable urban mobility - Norwegian relationships and comparisons An indicator system for environmentally friendly urban transport. TØI Report, I.
Costa, M. da S. (2008). Um índice de mobilidade urbana sustentável. [Tese de Doutorado], 248. www.teses.usp.br/teses/ disponiveis/18/18144/tde.../Tese MCOSTA.pdf

Costa, M. S., Silva, A. N. R., \& Ramos, R. A. R. (2005). Sustainable urban mobility: A comparative study and the basis for a management system in Brazil and Portugal. WIT Transactions on the Built Environment, 77, 323-332.

Danielis, R., Rotaris, L., \& Monte, A. (2018). Composite indicators of sustainable urban mobility: Estimating the rankings frequency distribution combining multiple methodologies. International Journal of Sustainable Transportation, 12(5), 380-395. https://doi.org/10.1080/15568318.2017.1377789

Dobranskyte-Niskota, A., Perujo, A., \& Pregl, M. (2007). Indicators to assess sustainability of transport activities. In European Commission Joint Research Centre Institute for Environment and Sustainability. https://doi.org/10.2788/54736

Gillis, D., Semanjski, I., \& Lauwers, D. (2016). How to monitor sustainable mobility in cities? Literature review in the frame of creating a set of sustainable mobility indicators. Sustainability (Switzerland), 8(1), 1-30. https://doi.org/10.3390/su8010029

Gössling, S. (2013). Urban transport transitions: Copenhagen, city of cyclists. Journal of Transport Geography, 33, 196-206. https://doi.org/10.1016/i.jtrangeo.2013.10.013

Guy, G. B., \& Kibert, C. J. (1998). Developing indicators of sustainability: US experience. Building Research and Information, 26(1), 39-45. https://doi.org/10.1080/096132198370092

Haghshenas, H., \& Vaziri, M. (2012). Urban sustainable transportation indicators for global comparison. Ecological Indicators, 15(1), 115-121. https://doi.org/10.1016/i. ecolind.2011.09.010

Indicators, T., Indicators, S. T., \& Litman, T. (2008). Sustainable Transportation Indicators. Transportation, November.

Jeekel, H. (2017). Social Sustainability and Smart Mobility: Exploring the relationship. Transportation Research Procedia, 25, 4296-4310. https://doi.org/10.1016/j.trpro.2017.05.254

Joumard, R., Gudmundsson, H., Arapis, G., Arce, R., \& Aschemann, R. (2010). Indicators of environmental sustainability in transport. An interdisciplinary approach to methods.

Kim, G., \& Author, F. (2011). Comparative Analysis of Transportation Sustainability in OECD Countries. Journal of the Eastern Asia Society for Transportation Studies, 9(April 2010), 82-97. https://doi.org/10.11175/eastpro.2011.0.34.0

Kolbasov, O. S. (1992). UN Conference on Environment and Development. Izvestiya - Akademiya Nauk, Seriya Geograficheskaya, 6(June), 47-54. https://doi. org/10.4135/9781412971867.n128

Kristle Nathan, H. S., \& Reddy, B. S. (2013). Urban transport sustainability indicators - Application of multi-view blackbox (MVBB) framework. International Journal of Environment and Sustainable Development, 12(3), 285-312. https://doi. org/10.1504/IJESD.2013.054955

Litman, T. (2007). Developing indicators for comprehensive and sustainable transport planning. Transportation Research Record, 2017, 10-15. https://doi.org/10.3141/2017-02

Litman, T. (2009). Sustainable Transportation Indicator Data Quality and Availability. 2010 Transportation Research Board Annual Meeting, 8.

Litman, T. (2013). The new transportation planning paradigm. ITE Journal (Institute of Transportation Engineers), 83(6), 20-28.

Liu, Z., Ren, Y., Shen, L., Liao, X., Wei, X., \& Wang, J. (2020). Analysis on the effectiveness of indicators for evaluating urban carrying capacity: A popularity-suitability perspective. Journal of Cleaner Production, 246, 119019. https://doi.org/10.1016/j. jclepro.2019.119019

LLJ .cl . (n.d.).

Marletto, G., \& Mameli, F. (2012). A participative procedure to select indicators of policies for sustainable urban mobility. Outcomes of a national test. European Transport Research Review, 4(2), 79-89. https://doi.org/10.1007/s12544-012-0075-8 
Marsden, G., \& Snell, C. (2009). The role of indicators, targets and monitoring in decision-support for transport. European Journal of Transport and Infrastructure Research, 9(3), 219-236. https://doi.org/10.18757/ejtir.2009.9.3.3308

Mitchell, G. (1996). Problems and Fundamentals of Sustainable Development Indicators. Sustainable Development, 4(1), 1-11. https://doi.org/10.1002/(sici)1099-1719(199603)4:1<1::aid$\underline{\mathrm{sd} 24>3.3 . \mathrm{co} ; 2-\mathrm{e}}$

Mitropoulos, L. K., \& Prevedouros, P. D. (2016). Incorporating sustainability assessment in transportation planning: an urban transportation vehicle-based approach. Transportation Planning and Technology, 39(5), 439-463. https://doi.org/10.10 $\underline{80 / 03081060.2016 .1174363}$

Munira, S., \& Santoso, D. S. (2017). Examining public perception over outcome indicators of sustainable urban transport in Dhaka city. Case Studies on Transport Policy, 5(2), 169-178. https://doi.org/10.1016/j.cstp.2017.03.011

Nicolas, J. P., Pochet, P., \& Poimboeuf, H. (2003). Towards sustainable mobility indicators: Application to the Lyons conurbation. Transport Policy, 10(3), 197-208. https://doi. org/10.1016/S0967-070X(03)00021-0

Noy, K., \& Givoni, M. (2018). Is "smart mobility" sustainable? Examining the views and beliefs of transport's technological entrepreneurs. Sustainability (Switzerland), 10(2). https://doi. org/10.3390/su10020422

Olofsson, Z., Hiselius, L., \& Várhelyi, A. (2016). Development of a tool to assess urban transport sustainability: The case of Swedish cities. International Journal of Sustainable Transportation, 10(7), 645-656. https://doi.org/10.1080/155683 18.2015.1055535

Organisation for Economic Co-operation and Development (OECD). (1999). Indicators for the Integration of Environmental Concerns Into Transport Policies. Environment Policy Committee, 98, 71.

Oviedo, D., \& Guzman, L. A. (2020). Revisiting accessibility in a context of sustainable transport: Capabilities and inequalities in Bogota. Sustainability (Switzerland), 12(11). https://doi. org/10.3390/su12114464

Ramani, T. L., Zietsman, J., Gudmundsson, H., Hall, R. P., $\&$ Marsden, G. (2011). Framework for sustainability assessment by transportation agencies. Transportation Research Record, 2242, 9-18. https://doi.org/10.3141/2242-02

Reisi, M., Aye, L., Rajabifard, A., \& Ngo, T. (2014). Transport sustainability index: Melbourne case study. Ecological Indicators, 43, 288-296. https://doi.org/10.1016/j. ecolind.2014.03.004

Sdoukopoulos, A., Nikolaidou, A., Pitsiava-Latinopoulou, M., \& Papaioannou, P. (2018). Use of social media for assessing sustainable urban mobility indicators. International Journal of Sustainable Development and Planning, 13(2), 338-348. https://doi.org/10.2495/SDP-V13-N2-338-348

Sdoukopoulos, A., Pitsiava-Latinopoulou, M., Basbas, S., \& Papaioannou, P. (2019). Measuring progress towards transport sustainability through indicators: Analysis and metrics of the main indicator initiatives. Transportation Research Part D: Transport and Environment, 67(December 2018), 316-333. https://doi.org/10.1016/j.trd.2018.11.020

Shiau, T. A., \& Liu, J. S. (2013). Developing an indicator system for local governments to evaluate transport sustainability strategies. Ecological Indicators, 34, 361-371. https://doi. org/10.1016/j.ecolind.2013.06.001

Steadman, P., Lautso, K., Wegener, M., Spiekermann, K., Sheppard, I., Martino, A., Domingo, R., \& Gayda, S. (2004). PROPOLIS: Planning and Research of Policies for Land Use and Transport for Increasing Urban Sustainability. 368. http://www.spiekermann-wegener.de/pro/pdf/PROPOLIS Final_Report.pdf

Thomé, A. M. T., Scavarda, L. F., \& Scavarda, A. J. (2016). Conducting systematic literature review in operations management. Production Planning and Control, 27(5), 408-420. https://doi.org/10.1080/09537287.2015.1129464

Web of Science [v.5.34] - Web of Science Core Collection Basic Search. (n.d.). Retrieved February 11, 2020, from http://apps. webofknowledge.com/WOS_GeneralSearch_input.do;jsessioni $\mathrm{d}=07208385 \mathrm{~EB} 014 \mathrm{E} 513 \mathrm{D} 47 \mathrm{~B} 70 \mathrm{~B} 56 \mathrm{BC} 1 \mathrm{C} 6 \mathrm{C}$ ?product=WOS\&sea rch mode $=$ GeneralSearch $\& S I D=C 3 w 97 i E R H 8 B B h Z W l F L B \& p r e f$ erencesSaved $=$

Yigitcanlar, T., Kamruzzaman, M., Foth, M., Sabatini-Marques, J., da Costa, E., \& Ioppolo, G. (2019). Can cities become smart without being sustainable? A systematic review of the literature. Sustainable Cities and Society, 45(June 2018), 348-365. https://doi.org/10.1016/j.scs.2018.11.033

Yin, R. K. (1994). Discovering the future of the case study method in evaluation research. Evaluation Practice, 15(3), 283-290. https://doi.org/10.1016/0886-1633(94)90023-X

Zheng, J., Garrick, N. W., Atkinson-Palombo, C., McCahill, C., \& Marshall, W. (2013). Guidelines on developing performance metrics for evaluating transportation sustainability. Research in Transportation Business and Management, 7, 4-13. https://doi.org/10.1016/j.rtbm.2013.02.001

Zietsman, J., Rilett, L. R., \& Kim, S. (2003). Sustainable Transportation Performance Measures for Developing Communities. 7(2). 